\title{
Influence of Polymorphisms in Genes Encoding for Insulin-Like Growth Factor (IGF)-I, Insulin, and IGF-Binding Protein (IGFBP)-3 on IGF-I, IGF-II, and IGFBP-3 Levels in Umbilical Cord Plasma
}

\author{
Eva Landmann ${ }^{\text {a }}$ Barbara Kollerits ${ }^{\mathrm{e}}$ Joachim Gerhard Kreuder ${ }^{\mathrm{c}}$ \\ Werner Friedrich Blum ${ }^{d}$ Florian Kronenberg ${ }^{e}$ Silvia Rudloff ${ }^{b}$ \\ a Department of Pediatric Hematology and Oncology, and bepartment of Pediatrics and Neonatology, Pediatric \\ Center, ' Pediatric Heart Center, Justus Liebig University, Giessen, and d Lilly Research Laboratories, Eli Lilly \\ and Company, Bad Homburg, Germany; ${ }^{e}$ Division of Genetic Epidemiology, Department of Medical Genetics, \\ Molecular and Clinical Pharmacology, Innsbruck Medical University, Innsbruck, Austria
}

\section{Key Words}

Polymorphism • IGF-I - IGF-II - IGFBP-3 - Umbilical cord plasma

\begin{abstract}
Background/Aims: In postnatal life, polymorphisms in the promoter region of IGFBP3 were associated with insulin-like growth factor binding protein (IGFBP)-3 plasma levels. Whether these associations exist in utero has not been studied yet. Polymorphisms in the IGF1 promoter (polymorphic CA-repeat) and the insulin gene variable number tandem repeats locus (INS VNTR) are further polymorphisms of interest, because associations with birth weight have been reported. We aimed to investigate associations between polymorphisms in the promoter regions of IGF1 (wild type $192 \mathrm{bp}$ ), IGFBP3 (rs2854744; rs13241830), and INS VNTR (rs689) with cord plasma levels of IGF-I, IGF-II, and IGFBP-3. Methods: We measured IGF-I, IGF-II, and IGFBP-3 concentrations in cord blood from 677 neonates and genotyped the selected polymorphisms. Results: Carriers of the minor allele of both polymorphisms in the IGFBP3 gene had, on average, 4-5\% lower
\end{abstract}

IGFBP-3 levels per copy of the respective minor allele ( $p=$ 0.002 and $p=0.028$ ) when compared to wild type carriers. The IGF1 promoter and the INS VNTR polymorphisms were not associated with IGF-I, IGF-II, or IGFBP-3 levels. Conclusions: Our data show associations of cord plasma IGFBP-3 levels and the IGFBP3 gene variants but not of IGF1 promoter and INS VNTR polymorphisms with IGF-I, IGF-II, or IGFBP-3 levels in utero.

Copyright $\odot 2012$ S. Karger AG, Basel

\section{Introduction}

In fetal life, insulin, insulin-like growth factor (IGF)-I, IGF-II, and IGF-binding protein (IGFBP)-3 are essential growth factors [1-3]. Until now, however, the influence of common genetic variations on the in utero regulation of these growth factors has been studied only scarcely.

With respect to genetic influences of IGFBP-3 synthesis in utero, two polymorphisms in the promoter region of the IGFBP3 gene $(-202 \mathrm{~A} / \mathrm{C}, \mathrm{rs} 2854744$ and $-185 \mathrm{C} / \mathrm{T}$, rs13241830) are of particular interest; in vitro, the -202

\section{KARGER}

Fax +4161306 1234

E-Mail karger@karger.ch

www.karger.com
(C) 2012 S. Karger AG, Basel

$1663-2818 / 12 / 0776-0341 \$ 38.00 / 0$

Accessible online at:

www.karger.com/hrp
Eva Landmann, MD, MPH

Department of Pediatric Hematology and Oncology

Pediatric Center, Justus Liebig University

Feulgenstrasse 12, DE-35392 Giessen (Germany)

Tel. +49 6419854 3400, E-Mail Eva.Landmann@paediat.med.uni-giessen.de 
$\mathrm{A} / \mathrm{C}$ and the $-185 \mathrm{C} / \mathrm{T}$ polymorphisms were recently shown to influence transcriptional activity of the IGFBP3 gene in a haplotype-dependent way [4]. In several studies, the $-202 \mathrm{~A} / \mathrm{C}$ polymorphism was consistently shown to be associated with circulating levels of IGFBP-3. Until now, these associations have only been reported in adult [5-10] and pediatric populations [11, 12].

However, regulation of circulating levels of IGFs and their binding proteins varies considerably throughout life. While growth hormone is the predominant stimulator of IGF-I and IGFBP-3 synthesis in postnatal life, fetal production mainly depends on nutrient supply of the fetus [1]. It is thus of interest whether the association reported in postnatal life also exists in utero when different regulatory mechanisms of IGF and IGFBP production occur. Verifying a robust association would affirm the independent effects of this genetic variation on IGFBP-3 levels and add information on molecular influences on the regulation of fetal growth factor synthesis.

Common genetic variation has been suspected to influence the intrauterine regulation of insulin, IGF-I, and IGF-II synthesis. A polymorphic CA-repeat (wild type $192 \mathrm{bp}$ ) in the promoter region of the IGF1 gene and an allele length variation at the variable number of tandem repeats (VNTR) locus in the promoter region of the insulin gene (INS; rs689) are interesting candidates because associations with birth weight have been described [13, 14], which were not confirmed by all studies [15-18]. In vitro, the INS VNTR polymorphism was shown to not only affect the expression of INS $[19,20]$ but also the expression of the nearby gene encoding for IGF-II [21].

Elucidating the influence of both polymorphisms on the in utero synthesis of IGFs and their binding proteins is of particular interest, since these polymorphisms have been hypothesized to explain the association between restricted fetal growth and an increased risk of diabetes and cardiovascular disease in later life, as reported in several population studies [22-24]. While insulin affects fetal growth and plays a crucial role in glucose homeostasis, IGF-I is also involved in glucose homeostasis $[25,26]$ and has been shown to be associated with cardiovascular disease [27-29]. If the specified polymorphisms affected circulating levels of IGFs and their binding proteins in utero, these associations would support their role in fetal growth and later susceptibility to diseases such as cardiovascular disease.

The purpose of this study was to investigate the relationship between the specified polymorphisms in the promoter region of the IGF1, the IGFBP3, and the insulin gene and their influence on concentrations of IGF-I,
IGF-II, and IGFBP-3 in umbilical cord plasma. Thereby, we aimed to gain deeper insights into the influence of common genetic variations on fetal IGF and IGFBP synthesis.

\section{Subjects, Materials, and Methods}

\section{Study Population}

Umbilical cord blood was prospectively collected from all neonates born between October 2004 and October 2006 at the Department of Obstetrics and Gynecology, Justus Liebig University of Giessen, Germany, and at the Department of Obstetrics and Gynecology, Asklepios Hospital, Lich, Germany, whose parents gave written informed consent for their child to participate in the study.

Immediately after delivery, umbilical cord blood samples were taken by the midwives. The samples were kept at $4^{\circ} \mathrm{C}$ for up to $24 \mathrm{~h}$ before centrifugation at 3,000 $\mathrm{g}$ for $3 \mathrm{~min}$. Cord plasma and cell pellet were separated and stored at $-20^{\circ} \mathrm{C}$ until analyzed.

Routine measurements of birth weight and length were registered and information about the pregnancy was taken from data documented at the prenatal visits in a standardized way. Information on further specific variables with theoretical or previously reported influence on fetal growth, such as parental weight and height, maternal smoking during pregnancy, and parental education, were obtained by interview. The calculation of gestational age was based on maternal menstrual history or on early prenatal ultrasound. Neonates of a gestational age $<37$ weeks were considered as born preterm. Being born extremely small for gestational age (ESGA), small for gestational age (SGA), appropriate for gestational age (AGA), or large for gestational age (LGA) was defined as a birth weight $<3$ rd, 3rd to $<10$ th, 10 th to $<90$ th, and $\geq 90$ th gender-specific percentile for German newborns [30], respectively. Maternal body mass index (BMI) was calculated by dividing the maternal prepregnancy weight $(\mathrm{kg})$ by the squared maternal length $(\mathrm{m})$. The variable hypertension was defined when systolic blood pressure values $\geq 140 \mathrm{~mm} \mathrm{Hg}$ and/or diastolic blood pressure values $\geq 90 \mathrm{~mm} \mathrm{Hg}$ were documented at the prenatal visits. The variable 'pregnancy weight gain' was calculated by subtracting maternal prepregnancy weight from maternal weight before delivery. The variable 'assisted reproduction' was defined as either in vitro fertilization or intracytoplasmic sperm injection. Maternal diabetes was defined as either type 1 diabetes or gestational diabetes with need for insulin therapy. All mothers who stated having smoked during pregnancy were classified as 'smokers'. Exclusion criteria were multiple births, unclear gestational age and, in the case of the neonates, suspected congenital infection syndromes, hemodynamically relevant cardiac malformations, identifiable syndromes, inborn endocrine diseases, and errors of metabolism. The analyses were confined to Caucasian neonates.

The study was approved by the Ethics Committee of the Justus Liebig University, Giessen.

\section{Genotyping}

DNA Isolation and Quantification. Genomic DNA without prior cell sorting as has been described by others [e.g. 31, 32] was purified from buffy coats of umbilical cord blood samples using the QIAamp ${ }^{\circledR}$ DNA Blood Mini kit (Qiagen GmbH, Hilden, Ger- 
many). DNA was quantified using the human DNA Quantifiler ${ }^{\circledR}$ kit (P/N 4343895, Applied Biosystems, Foster City, Calif., USA).

INS VNTR or HphI -23 A/T (rs689). DNA samples were genotyped for the class I/III INS VNTR polymorphism at the $-23 \mathrm{~A} / \mathrm{T}$ HphI site located at nucleotide 4462 on GenBank sequence L15440. This polymorphism is in virtually complete linkage disequilibrium with the INS VNTR polymorphism [33]. The region of the promoter of the insulin gene was amplified with PCR using an SNP genotyping assay ( $5^{\prime}>$ nuclease assay). Primers were supplied by MWG Biotech (Ebersberg, Germany) with the forward primer being 5'-CCATGGCAGAAGGACAGTGA-3' and the reverse primer 5'-GGGCACCTGGCCTTCAG-3'. Fluorescence and minor groove binder (MGB) labeled probes (Applied Biosystems, Warrington, UK) were used to discriminate for the two allelic variations: 6FAM-CCTGCCTGTCTCCCAGA-MGB and VIC-CTGCCTGTCACCCAGA-MGB. PCR amplification was performed in $25 \mu \mathrm{l}$ volume containing $20 \mathrm{ng}$ genomic DNA, 10 $\mathrm{pmol} / \mathrm{l}$ of each primer, $3 \mathrm{pmol} / \mathrm{l}$ of each probe, and TaqMan ${ }^{\circledR} \mathrm{Uni}$ versal Master Mix containing buffer and AmpliTaq Gold ${ }^{\circledR}$ DNA polymerase (Applied Biosystems). After a pre-read run at $50^{\circ} \mathrm{C}$ to determine baseline fluorescence, amplification was performed at the following PCR conditions: $50^{\circ} \mathrm{C}$ for $2 \mathrm{~min}$ and $95^{\circ} \mathrm{C}$ for $10 \mathrm{~min}$ as an initial step, followed by 40 cycles of denaturation at $92^{\circ} \mathrm{C}$ for $15 \mathrm{~s}$ and annealing/extension at $60^{\circ} \mathrm{C}$ for $1 \mathrm{~min}$ on an ABI 7500 real-time PCR system (Applied Biosystems). A post-read at $60^{\circ} \mathrm{C}$ was carried out to get an allelic discrimination.

IGFBP3 -185 C/T (rs13241830). DNA was genotyped for IGFBP3 $-185 \mathrm{C} / \mathrm{T}$ polymorphism using a TaqMan ${ }^{\circledR}$ Pre-Designed SNP Genotyping Assay (C_1842666_10, Applied Biosystems) according to the manufacturer's instructions. A mix of primer and probes was supplied, the latter being $5^{\prime}$-fluorescence and 3 '-MGB labeled. Reagents and PCR conditions were used as described above.

IGFBP3 -202 A/C (rs2854744). Genotyping was performed

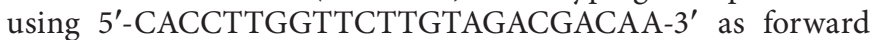
primer and 5'-GGCGTGCAGCTCGAGACT-3' as reverse primer. TaqMan probes were FAM-CTCGTGCTCACGCC-MGB and VIC-TCCTCGTGCGCACG-MGB. Universal master mix and PCR conditions were used as described above. All SNPs were run in duplicate; concordance for replicate samples was $100 \%$.

IGF-I Microsatellite Length Polymorphism. The microsatellite length polymorphism in the promoter region of the IGF1 gene was determined by fragment length analysis as described previously [34].

\section{Biochemical Analyses}

IGF-I and IGFBP-3 concentrations were measured using a radioimmunoassay (RIA) as described previously by Blum and Ranke [35]. For IGF-I, intra- and interassay coefficients of variation were 1.6 and $6.4 \%$, respectively. Sensitivity was $0.3 \mu \mathrm{g} / \mathrm{l}$ under standard conditions. For IGFBP-3, intra- und interassay coefficients of variation were 1.9 and $9.2 \%$, respectively, with a sensitivity of $0.13 \mathrm{mg} / \mathrm{l}$ under standard conditions.

IGF-II concentrations were measured by RIA using a commercially available assay (Mediagnost, Tübingen, Germany). All samples were run in duplicate.

\section{Statistical Analyses}

To compare characteristics of neonates born at term and neonates born preterm we applied unpaired t tests, nonparametric Wilcoxon tests, Pearson's $\chi^{2}$ test ANOVA, and unpaired Kruskal-
Wallis test where appropriate. Pearson's correlation coefficient (r) and Spearman's $\rho\left(r_{s}\right)$ were used to calculate the correlations between continuous variables with normal and non-normal distributions as appropriate, and Spearman's $\rho\left(r_{s}\right)$ was used for correlation analysis between continuous and categorical variables. Genotype and allele frequencies were estimated, and a test of Hardy-Weinberg equilibrium was performed using the asymptotic $\chi^{2}$ test. Linkage disequilibrium between the $-202 \mathrm{~A} / \mathrm{C}$ and the $-185 \mathrm{C} / \mathrm{T}$ polymorphism was assessed by the correlation coefficient $r$ and Lewontin's D'. Haplotypes based on the two SNPs from IGFBP3 were estimated via the expectation maximization algorithm by the SASe procedure PROC HAPLOTYPE (version 9.1, release 2004).

General linear regression models of various adjustments were designed to assess the influence of the investigated polymorphisms on the cord plasma levels of IGF-I, IGF-II, and IGFBP-3. An additive genetic model, i.e. a model estimating the change of mean IGF-I, IGF-II, and IGFBP-3 levels per copy of the minor allele, was applied. The covariate 'birth weight for gestational age' as an indicator of pathological intrauterine growth was categorized as ESGA, SGA, AGA, and LGA and alternatively as categorization of gender-specific quintiles derived from the studied population. An additional analysis for IGFBP-3 included the haplotypes instead of single SNPs to the model. All models were run including (a) all children and (b) only the children born at term.

All analyses were conducted in SPSS version 18.0 software (SPSS Inc., Chicago, Ill., USA). Statistical significance of differences was assumed if $\mathrm{p}$ was $<0.05$.

\section{Results}

A total of 754 parents consented to enroll their children in the study. Among those children, 77 did not fulfill inclusion criteria (at least one parent being non-Caucasian: $\mathrm{n}=22$; twin birth: $\mathrm{n}=30$; unclear gestational age, suspected congenital infection syndromes, hemodynamically relevant cardiac malformation, identifiable syndrome, endocrine disease, or inborn error of metabolism: $\mathrm{n}=25)$. Thus, 677 neonates were included in the study. Basic maternal and infant characteristics are presented in table 1 for all 677 neonates and stratified for neonates born at term and those born preterm.

\section{Biochemical Analyses}

For all neonates, mean cord plasma concentrations of IGF-I, IGF-II, and IGFBP-3 were $59.8 \pm 30.0 \mu \mathrm{g} / \mathrm{l}, 407 \pm$ $137 \mu \mathrm{g} / \mathrm{l}$, and $1.40 \pm 0.46 \mathrm{mg} / \mathrm{l}$, respectively. IGF-I concentrations were higher in female than in male neonates (64.2 \pm 32 vs. $55.6 \pm 28 \mu \mathrm{g} / \mathrm{l} ; \mathrm{p}=0.0002)$ and increased with increasing birth weight for gestational age, as indicated by the categories ESGA, SGA, AGA, and LGA ( $\mathrm{p}<$ 0.0001 ; table 2 ), as well as by the gender-specific quintiles 
Table 1. Maternal and neonate characteristics of 677 pregnancies

\begin{tabular}{|c|c|c|c|c|}
\hline Variable & $\begin{array}{l}\text { All births } \\
(\mathrm{n}=677)\end{array}$ & $\begin{array}{l}\text { Neonates born at term } \\
(\mathrm{n}=555)\end{array}$ & $\begin{array}{l}\text { Neonates born preterm } \\
(\mathrm{n}=122)\end{array}$ & $\mathrm{p}^{\mathrm{b}}$ \\
\hline ESGA/SGA/AGA/LGA, \% & $2 / 8 / 77 / 13$ & $2 / 8 / 78 / 12$ & $3 / 8 / 73 / 16$ & 0.50 \\
\hline Mean maternal age $\pm S D$, years & $30.6 \pm 6$ & $30.7 \pm 6$ & $30.3 \pm 6$ & 0.52 \\
\hline Primipara, \% & 39 & 37 & 48 & 0.0234 \\
\hline Smoking during pregnancy, $\%^{\mathrm{a}}$ & 13 & 12 & 19 & 0.05 \\
\hline Range & $26-42$ & $37-42$ & $26-36$ & \\
\hline Mean birth weight $\pm \mathrm{SD}, \mathrm{g}$ & $3,243 \pm 653$ & $3,445 \pm 447$ & $2,327 \pm 656$ & $<0.0001$ \\
\hline Median & 3,340 & 3,430 & 2,405 & \\
\hline Range & $750-4,910$ & $1,790-4,910$ & $750-4,170$ & \\
\hline Male/female, \% & $51 / 49$ & $51 / 49$ & $53 / 47$ & 0.62 \\
\hline
\end{tabular}

${ }^{a}$ Ever smoked during pregnancy on a regular basis. ${ }^{\mathrm{b}} \mathrm{p}$ value for comparing neonates born at term and neonates born preterm.

Table 2. Cord plasma concentrations of IGF-I, IGF-II, and IGFBP-3 within the categories ESGA, SGA, AGA, and LGA

\begin{tabular}{lccccc}
\hline & ESGA $(\mathrm{n}=12)$ & SGA $(\mathrm{n}=54)$ & AGA $(\mathrm{n}=523)$ & LGA $(\mathrm{n}=88)$ & $\mathrm{p}$ value \\
\hline IGF-I, $\mu \mathrm{g} / \mathrm{l}$ & $22.5 \pm 16.9$ & $36.9 \pm 20.7$ & $59.6 \pm 27.6$ & $79.7 \pm 34.6$ & $<0.0001$ \\
IGF-II, $\mu \mathrm{g} / \mathrm{l}$ & $411 \pm 152$ & $420 \pm 160$ & $408 \pm 139$ & $398 \pm 108$ & 0.84 \\
IGFBP-3, $\mathrm{mg} / \mathrm{l}$ & $0.99 \pm 0.24$ & $1.20 \pm 0.43$ & $1.39 \pm 0.45$ & $1.59 \pm 0.47$ & $<0.0001$ \\
\hline
\end{tabular}

Concentrations are provided as means $\pm \mathrm{SD}$.

Table 3. Cord plasma concentrations of IGF-I, IGF-II, and IGFBP-3 within gender-specific quintiles of birth weight for gestational age - boys

\begin{tabular}{|c|c|c|c|c|c|c|}
\hline & $\begin{array}{l}\text { Quintile } 1 \\
(n=62)\end{array}$ & $\begin{array}{l}\text { Quintile } 2 \\
(\mathrm{n}=75)\end{array}$ & $\begin{array}{l}\text { Quintile } 3 \\
(\mathrm{n}=71)\end{array}$ & $\begin{array}{l}\text { Quintile } 4 \\
(\mathrm{n}=73)\end{array}$ & $\begin{array}{l}\text { Quintile } 5 \\
(\mathrm{n}=65)\end{array}$ & $\begin{array}{l}\mathrm{p} \\
\text { value }\end{array}$ \\
\hline IGF-I, $\mu \mathrm{g} / 1$ & $37.0 \pm 18.7$ & $47.5 \pm 20.2$ & $55.5 \pm 26.9$ & $65.9 \pm 24.3$ & $71.6 \pm 33.4$ & $<0.0001$ \\
\hline IGF-II, $\mu \mathrm{g} / \mathrm{l}$ & $397 \pm 138$ & $413 \pm 154$ & $418 \pm 154$ & $423 \pm 155$ & $402 \pm 115$ & 0.83 \\
\hline IGFBP-3, mg/l & $1.16 \pm 0.38$ & $1.36 \pm 0.45$ & $1.29 \pm 0.35$ & $1.47 \pm 0.50$ & $1.41 \pm 0.44$ & $<0.0001$ \\
\hline
\end{tabular}

Concentrations are provided as mean $\pm \mathrm{SD}$.

of birth weight of the studied population $(\mathrm{p}<0.0001$; tables 3, 4).

IGF-II concentrations did not differ between female and male neonates $(404.4 \pm 129$ vs. $411.2 \pm 144 \mu \mathrm{g} / \mathrm{l} ; \mathrm{p}=$ 0.52 ) and were not influenced by birth weight for gestational age (table 2) or gender-specific quintiles of birth weight (tables 3, 4). IGFBP-3 concentrations were higher in female than in male neonates $(1.45 \pm 0.48$ vs. $1.34 \pm$ $0.44 \mathrm{mg} / \mathrm{l} ; \mathrm{p}=0.0026)$ and correlated positively with IGFI levels $(r=0.41 ; \mathrm{p}<0.0001)$ and with gestational age $\left(\mathrm{r}_{\mathrm{s}}=\right.$ $0.11 ; \mathrm{p}=0.003)$. IGFBP-3 concentrations increased with increasing birth weight for gestational age $(\mathrm{p}<0.0001$; table 2$)$ and across the gender-specific quintiles ( $<<0.0001$; tables 3, 4). 
Table 4. Cord plasma concentrations of IGF-I, IGF-II, and IGFBP-3 within gender-specific quintiles of birth weight for gestational age - girls

\begin{tabular}{|c|c|c|c|c|c|c|}
\hline & $\begin{array}{l}\text { Quintile } 1 \\
(\mathrm{n}=62)\end{array}$ & $\begin{array}{l}\text { Quintile } 2 \\
(\mathrm{n}=67)\end{array}$ & $\begin{array}{l}\text { Quintile } 3 \\
(n=69)\end{array}$ & $\begin{array}{l}\text { Quintile } 4 \\
(\mathrm{n}=68)\end{array}$ & $\begin{array}{l}\text { Quintile } 5 \\
(n=63)\end{array}$ & $\mathrm{p}$ value \\
\hline IGF-I, $\mu \mathrm{g} / \mathrm{l}$ & $42.0 \pm 25.6$ & $56.6 \pm 29.1$ & $68.0 \pm 30.7$ & $68.0 \pm 24.9$ & $85.8 \pm 31.2$ & $<0.0001$ \\
\hline IGFBP-3, mg/l & $1.23 \pm 0.36$ & $1.40 \pm 0.46$ & $1.41 \pm 0.40$ & $1.53 \pm 0.50$ & $1.68 \pm 0.53$ & $<0.0001$ \\
\hline
\end{tabular}

Concentrations are provided as mean $\pm \mathrm{SD}$.

Table 5. Genotype frequency distributions in the study population

\begin{tabular}{|c|c|c|c|c|}
\hline IGFBP-3 A/C & $\begin{array}{l}\text { AA } \\
138(20.5 \%)\end{array}$ & $\begin{array}{l}\text { CA } \\
343(51.0 \%)\end{array}$ & $\begin{array}{l}\text { CC } \\
191(28.4 \%)\end{array}$ & $54 \%^{\mathrm{a}}$ \\
\hline IGFBP-3 C/T & $\begin{array}{l}\text { CC } \\
312(46.6 \%)\end{array}$ & $\begin{array}{l}\text { CT } \\
289(43.2 \%)\end{array}$ & $\begin{array}{l}\text { TT } \\
68(10.2 \%)\end{array}$ & $32 \%$ \\
\hline IGF-I 192 bp & $\begin{array}{l}192 / 192 \\
264(39.1 \%)\end{array}$ & $\begin{array}{l}192 / x \\
315(46.7 \%)\end{array}$ & $\begin{array}{l}\mathrm{x} / \mathrm{x} \\
96(14.2 \%)\end{array}$ & $38 \%^{\mathrm{b}}$ \\
\hline
\end{tabular}

a The $\mathrm{C}$ allele is designated as 'minor allele' in order to be consistent with previous studies [e.g. 9].

b Non-carrying of the 192 bp allele is designated as 'minor allele'.

\section{Genotyping Results}

Genotype distributions of all four polymorphisms are shown in table 5 . For the IGF1 promoter polymorphism, nine different alleles were identified, the most frequent being the 192bp allele. For all polymorphisms, no significant differences across the three genotypes were found with respect to gender and the percentages of children born ESGA, SGA, AGA, or LGA. The genotype distributions were comparable to previously reported distributions [13, $16,17]$ and were in Hardy-Weinberg equilibrium $(\mathrm{p}>$ 0.50 ). The minor allele frequencies for the polymorphisms ranged between 0.29 and 0.54 . Lewontin's D' of the -185 and -202 polymorphisms of IGFBP3 was almost unity $\left(D^{\prime}=0.9934\right)$ with a correlation coefficient of $r=0.63$.

\section{Associations between Genotypes and Cord Blood Levels of IGF-I, IGF-II, and IGFBP-3}

Associations of the polymorphisms in the promoter region of the IGFBP3 gene with IGFBP-3 levels were calculated in a linear regression model. The variables gender, gestational age, IGF-I, and birth weight for gestational age were included in the model. In order to identify further variables for inclusion in the linear regression model we chose the following approach: at first, correlations between the concentrations of IGF-I and IGFBP-3 and further variables with a theoretical or previously reported influence on birth weight (i.e. parity, maternal hypertension, assisted reproduction, maternal pregnancy weight gain, maternal BMI, maternal diabetes, and smoking during pregnancy) were calculated. Among these variables, the variables parity, maternal hypertension, weight gain during pregnancy, maternal diabetes, and smoking during pregnancy were shown to be correlated with IGF-I concentrations $(\mathrm{p}<0.05)$. The variable maternal BMI was shown to be correlated with IGFBP-3 concentrations $(\mathrm{p}=$ 0.028). In a second step, all these variables which were shown to be correlated with either IGF-I or to IGFBP-3 concentrations were included in the model.

Both polymorphisms in the promoter region of the IGFBP3 gene were significantly associated with IGFBP-3 
Table 6. Mean plasma IGFBP-3 concentrations (mg/l) by genotypes in all neonates and in neonates born at term

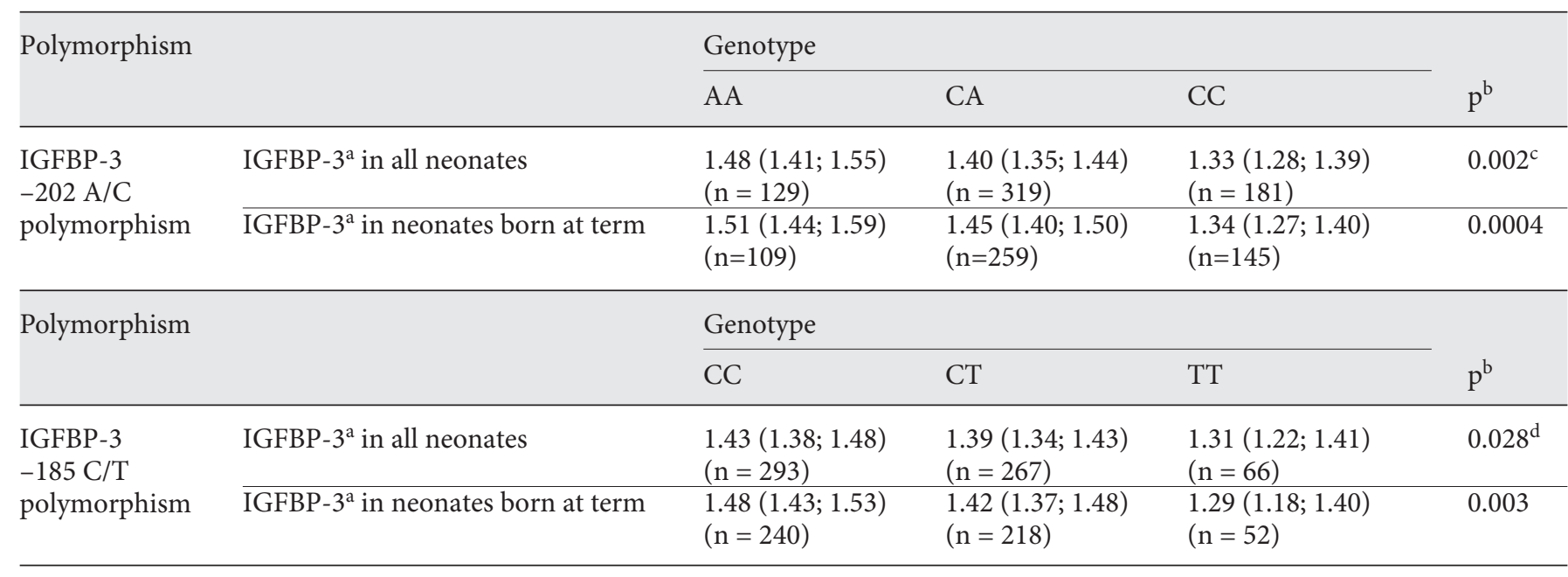

${ }^{a}$ Values are means and 95\% CI [adjusted for gender, gestational age, IGF-I, birth weight for gestational age (categories ESGA, SGA, AGA, and LGA)], maternal BMI, parity hypertension, pregnancy weight gain, maternal diabetes, and smoking during pregnancy). ${ }^{b} \mathrm{p}$ value for additive models. ${ }^{c}$ Regression formula: IGFBP- $3 \mathrm{mg} / \mathrm{l}=-0.271-0.073^{*}$ each copy of the minor allele of the IGFBP-3 gene $-0.73^{*}$ gender $[$ male $=1]+0.028^{*}$ gestational age [week] $+0.111^{*}$ weight for gestational age [categorized as ESGA/ SGA/AGA/LGA $]+0.005^{*}$ IGF-I $[\mu \mathrm{g} / \mathrm{l}]+0.003^{*} \mathrm{BMI}\left[\mathrm{kg} / \mathrm{m}^{2}\right]-$ $0.008^{*}$ parity $+0.027^{*}$ hypertension [yes $=1$ ] $-0.001^{*}$ weight gain in pregnancy $[\mathrm{kg}]-0.41^{*}$ maternal diabetes $[$ yes $=1]+0.099^{*}$ smoking during pregnancy [yes $=1]$. ${ }^{\mathrm{d}}$ IGFBP-3 $\mathrm{mg} / \mathrm{l}=-0.333-$ $0.054^{*}$ each copy of the minor allele of the IGFBP- 3 gene $-0.64^{*}$ gender $[$ male $=1]+0.029^{*}$ gestational age $[$ week $]+0.105^{*}$ weight for gestational age [categorized as ESGA/SGA/AGA/LGA] + $0.005^{*}$ IGF-I $[\mu \mathrm{g} / \mathrm{l}]+0.003^{*}$ BMI $\left[\mathrm{kg} / \mathrm{m}^{2}\right]-0.009^{*}$ parity + $0.043^{*}$ hypertension [yes $=1$ ] $-0.001^{*}$ weight gain in pregnancy $[\mathrm{kg}]-0.051^{*}$ maternal diabetes [yes $\left.=1\right]+0.089^{*}$ smoking during pregnancy [yes $=1$ ]. levels (table 6). The -202 A/C polymorphism of IGFBP3 showed a clear additive association per copy of the $\mathrm{C}$ allele with mean IGFBP- 3 concentrations of $1.48,1.40$, and $1.33 \mathrm{mg} / \mathrm{l}$ for 0,1 , and 2 copies of the $\mathrm{C}$ allele, respectively $(\mathrm{p}=0.002)$. In this linear regression model, each copy of the minor allele decreased the IGFBP-3 levels adjusted for gender, gestational age, IGF-I, 'birth weight for gestational age', parity, maternal BMI, maternal hypertension, weight gain during pregnancy, maternal diabetes, and smoking during pregnancy by $0.073 \mathrm{mg} / \mathrm{l}$ on average, which translates to a relative decrease of $5 \%$. This association was slightly more pronounced when the analyses were confined to neonates born at term $(\mathrm{p}=0.0004)$. We observed similar results irrespective of whether we adjusted for 'birth weight for gestational age' categorized by the gender-specific quintiles or classified as ESGA, SGA, AGA, or LGA. Very similar results were obtained for the $-185 \mathrm{C} / \mathrm{T}$ polymorphism of IGFBP3 with an average decrease of each copy of the T allele by $0.054 \mathrm{mg} / \mathrm{l}(\mathrm{p}=0.028$; table 6). Again, this association was more pronounced when the analyses were confined to neonates born at term $(\mathrm{p}=0.003)$.
Three common (AC, CC, and CT) and one rare haplotype (AT) derived from these two polymorphisms were identified. The rare haplotype was not analyzed in the models. Consistent with the single polymorphism analysis, individuals carrying two copies of the haplotype AC had the highest mean IGFBP-3 concentrations when compared to those carrying one or no copy of this haplotype [additive model, p values between 0.0012 (adjusted for gender, gestational age, IGF-I, and birth weight for gestational age classified as ESGA, SGA, AGA, or LGA) and 0.0062 (adjusted for gender, gestational age, sum of IGF-I and IGF-II, and birth weight for gestational age classified as ESGA, SGA, AGA, or LGA)]. The haplotype CT was associated with a decrease in IGFBP-3 concentrations for individuals carrying two copies of the haplotype CT when compared to those carrying one or no copy of this haplotype [additive model, $\mathrm{p}$ values between 0.0347 (adjusted for gender, gestational age, IGF-I, and birth weight for gestational age classified as ESGA, SGA, AGA, or LGA) and 0.086 (adjusted for gender, gestational age, sum of IGF-I and IGF-II, and birth weight for gestational age classified as ESGA, SGA, AGA, or LGA)]. The haplo- 
type CC was associated with a decrease in IGFBP-3 concentrations, however, not significantly.

We observed no significant associations between the IGFBP3 promoter polymorphisms and the levels of IGF-I and IGF-II and no association between the INS VNTR polymorphism and the $I G F 1$ promoter polymorphism with cord plasma levels of IGF-I, IGF-II, or IGFBP-3.

\section{Discussion}

In this study, we investigated the influence of polymorphisms in the promoter regions of insulin, $I G F 1$, and IGFBP3 on cord plasma levels of IGFs and IGFBP-3 in 677 neonates. We observed strong associations of polymorphisms within the promoter of the IGFBP3 gene and IGFBP-3 concentrations but no associations between the other polymorphisms and the measured cord plasma levels. Limitations of the study are that we included a total of 677 neonates which limits the power to detect smaller effects. Furthermore, the study is not strictly population based. We do not have any hint for but can neither definitely exclude a selection bias. As a technical restriction, it seems noteworthy that we used cord blood cells without prior cell sorting for genetic analyses as has been done previously $[31,32]$. Although cord blood contains a mixture of different cell types, the pivotal cell population is of fetal origin.

\section{IGFBP3 Polymorphisms}

The influence of IGFBP 3 polymorphisms on circulating IGFBP-3 concentrations has been studied in several populations. For the -202 IGFBP3 A/C polymorphism in the IGFBP3 gene, a clear trend of decreasing IGFBP-3 concentration per copy of the $\mathrm{C}$ allele has consistently been reported in adult $[5-10]$ and pediatric $[11,12]$ populations. Cord plasma levels of hormones and hormonelike substances, such as the IGFs and IGFBPs, reflect their intrauterine synthesis. In utero, however, IGFBP-3 synthesis underlies considerably different regulatory mechanisms as compared to postnatal life.

Despite these pronounced 'environmental' influences, the association between the two IGFBP3 polymorphisms with IGFBP-3 concentration remained significant in all models even if we corrected for multiple hypotheses testing. To our knowledge, this is the first study demonstrating an association between these IGFBP3 polymorphisms and IGFBP-3 concentration in cord plasma, which underscores the pronounced and stable genetic regulation of IGFBP-3 levels by this gene over life span.

Determinants of IGF-I, IGF-II, and IGFBP-3 Levels
In addition, we identified, for the first time, a significant association between the -185 IGFBP3 polymorphism and cord plasma concentrations of IGFBP-3. This finding is in line with in vitro findings showing a significant haplotype-dependent transcriptional activity of both promoter polymorphisms [4]. Individuals carrying two copies of the most common haplotype AC in our study had the highest mean cord plasma IGFBP-3 levels. There was a difference of $8.4-12.2 \%$ in mean IGFBP-3 cord blood levels for the $-185 \mathrm{C} / \mathrm{T}$ IGFBP3 polymorphism as well as for the $-202 \mathrm{~A} / \mathrm{C} I G F B P 3$ polymorphism between individuals homozygous for the rare allele compared to wild type carriers. These differences correspond to ten 'centiles', e.g. 10th to 20th percentile, in reference values for IGFBP-3 in newborns [36]. The influence of these two polymorphisms on IGFBP-3 levels is of interest not only with respect to growth regulation. In epidemiological studies, IGFBP-3 levels have been associated with cancer risk $[5,37,38]$, and in vitro studies suggest a role for IGFBP-3 in the development of insulin resistance [39, 40].

\section{Polymorphisms in the Insulin Gene and IGF1 Gene}

The two polymorphisms investigated in the insulin gene and in the IGF1 gene both had no effect on cord plasma concentrations of IGFs and IGFBP-3. Experimental data in term placenta had indicated that the INS VNTR polymorphism affects the expression of the IGF2 gene [21] with class III alleles being associated with lower IGF-II transcription. This in vitro finding contrasts with findings from Ong et al. [41] who investigated cord blood levels of 353 neonates and reported slightly higher IGF-II levels for homozygote carriers of the class III alleles. In our markedly larger population of newborns, however, we observed no association between this polymorphism and IGF-II cord plasma concentration. In 1998, Dunger et al. [13] reported higher birth weights in class III homozygotes. This finding has not been confirmed in other populations $[16,17,34,42]$. Absent associations between the INS VNTR polymorphism and birth weight are in line with absent associations between this polymorphism and IGF-II cord blood levels as demonstrated in our study. However, intrauterine growth is affected by many factors; thus, the results from genetic association studies can be very variable. Similarly, several mechanisms underlying fetal programming of adult disease such as programming of the cortisol axis [43] or of angiotensin receptors [44] have been suggested. Furthermore, postnatal growth and weight gain after intrauterine growth restriction have been shown to be in- 
volved in developing metabolic syndrome associated with reduced fetal growth [45-47]. This could explain the discrepancy to prior publications.

The absence of the $192 \mathrm{bp}$ allele of the IGF1 promoter polymorphism has been linked to low birth weight [14], which was, however, not confirmed by other studies [15, 34]. Whether this polymorphism influences IGF-I levels in cord plasma has not been studied yet. In adults, conflicting results have been reported with respect to the influence of the $192 \mathrm{bp}$ allele on circulating IGF-I concentrations $[7,15,48,49]$. A recent study in 160 Japanese neonates did not find an association with IGF-I levels, which were, however, not measured in cord plasma but at day 5 after birth [50]. This finding is in line with our results. The Japanese group, however, identified an association between IGF-I concentrations and a 196-bp allele, which had a very low frequency $(<1 \%)$ in our population.

Taken together, our data do not show associations between the IGF1 promoter polymorphism or the investigated polymorphism in the insulin gene and IGF cord plasma levels. Our data thus do not support the hypothesis that the investigated polymorphisms influence IGF synthesis in utero and thereby affect birth weight. Genetic variants other than those investigated in our study might underlie the association between low birth weight and adult disease such as variants at loci near the gene encoding for cyclin L 1 (CCNL1) and the leucine, glutamate and lysine rich 1 (LEKR1) locus, in the CDKAL1 locus and in the genes encoding for adenylyl cyclase 5 (ADCY5) or for IGFBP2, which have all been described recently [44-46].

\section{Conclusions}

This is the first study showing a clear association between the IGFBP 3 promoter polymorphisms and IGFBP-3 cord plasma concentration. The study thus provides a first hint that also in utero, there is a stable influence of these polymorphisms on IGFBP-3 synthesis. Furthermore, our data do not provide evidence that the investigated polymorphisms in the insulin and in the IGF1 gene influence IGF cord plasma levels or affect birth weight through IGF levels in utero.

\section{Acknowledgement}

We thank the parents who consented to enroll their children in the study. We thank Marcel Zoremba for his excellent technical assistance in genotyping. We are especially grateful to the midwives and nurses for their cooperation and help in recruitment. This work was supported by the Federal State of Hesse, Germany (Hessisches Ministerium für Wissenschaft und Kunst, 'MenschErnährung-Umwelt').

\section{Disclosure Statement}

The authors of this study have no conflict of interest and no financial interest that could be perceived as prejudicing the impartiality of the research reported.

\section{References}

1 Murphy VE, Smith R, Giles WB, Clifton VL: Endocrine regulation of human fetal growth: the role of the mother, placenta, and fetus. Endocr Rev 2006;27:141-169.

-2 Juul A, Dalgaard P, Blum WF, Bang P, Hall K, Michaelsen KF, Muller J, Skakkebaek NE: Serum levels of insulin-like growth factor (IGF)-binding protein-3 (IGFBP-3) in healthy infants, children, and adolescents: the relation to IGF-I, IGF-II, IGFBP-1, IGFBP-2, age, sex, body mass index, and pubertal maturation. J Clin Endocrinol Metab 1995;80:2534-2542.

-3 Godfrey KM, Hales CN, Osmond C, Barker DJ, Taylor KP: Relation of cord plasma concentrations of proinsulin, 32-33 split proinsulin, insulin and C-peptide to placental weight and the baby's size and proportions at birth. Early Hum Dev 1996;46:129-140.
-4 Paquette J, Bessette B, Ledru E, Deal C: Identification of upstream stimulatory factor binding sites in the human IGFBP 3 promoter and potential implication of adjacent single-nucleotide polymorphisms and responsiveness to insulin. Endocrinology 2007;148: 6007-6018.

-5 Al-Zahrani A, Sandhu MS, Luben RN, Thompson D, Baynes C, Pooley KA, Luccarini C, Munday H, Perkins B, Smith P, Pharoah PD, Wareham NJ, Easton DF, Ponder BA, Dunning AM: IGF1 and IGFBP3 tagging polymorphisms are associated with circulating levels of IGF1, IGFBP3 and risk of breast cancer. Hum Mol Genet 2006;15:1-10.

-6 Cheng I, DeLellis Henderson K, Haiman CA, Kolonel LN, Henderson BE, Freedman ML, Le Marchand L: Genetic determinants of circulating insulin-like growth factor
(IGF)-I, IGF binding protein (BP)-1, and IGFBP-3 levels in a multiethnic population. J Clin Endocrinol Metab 2007;92:36603666.

7 Jernstrom H, Deal C, Wilkin F, Chu W, Tao Y, Majeed N, Hudson T, Narod SA, Pollak $\mathrm{M}$ : Genetic and nongenetic factors associated with variation of plasma levels of insulin-like growth factor-I and insulin-like growth factor-binding protein-3 in healthy premenopausal women. Cancer Epidemiol Biomarkers Prev 2001;10:377-384.

$\checkmark 8$ Deal C, Ma J, Wilkin F, Paquette J, Rozen F, Ge B, Hudson T, Stampfer M, Pollak M: Novel promoter polymorphism in insulin-like growth factor-binding protein-3: correlation with serum levels and interaction with known regulators. J Clin Endocrinol Metab 2001;86:1274-1280. 
\9 Canzian F, McKay JD, Cleveland RJ, Dossus L, Biessy C, Rinaldi S, Landi S, Boillot C, Monnier S, Chajes V, Clavel-Chapelon F, Tehard B, Chang-Claude J, Linseisen J, Lahmann $\mathrm{PH}$, Pischon T, Trichopoulos D, Trichopoulou A, Zilis D, Palli D, Tumino R, Vineis P, Berrino F, Bueno-de-Mesquita HB, van Gils CH, Peeters PH, Pera G, Ardanaz E, Chirlaque MD, Quiros JR, Larranaga N, Martinez-Garcia C, Allen NE, Key TJ, Bingham SA, Khaw KT, Slimani N, Norat T, Riboli E, Kaaks R: Polymorphisms of genes coding for insulin-like growth factor 1 and its major binding proteins, circulating levels of IGF-I and IGFBP-3 and breast cancer risk: results from the EPIC study. Br J Cancer 2006;94:299-307.

-10 Schumacher FR, Cheng I, Freedman ML, Mucci L, Allen NE, Pollak MN, Hayes RB, Stram DO, Canzian F, Henderson BE, Hunter DJ, Virtamo J, Manjer J, Gaziano JM, Kolonel LN, Tjonneland A, Albanes D, Calle EE, Giovannucci E, Crawford ED, Haiman CA, Kraft P, Willett WC, Thun MJ, Le Marchand L, Kaaks R, Feigelson HS, Bueno-de-Mesquita HB, Palli D, Riboli E, Lund E, Amiano P, Andriole G, Dunning AM, Trichopoulos D, Stampfer MJ, Key TJ, Ma J: A comprehensive analysis of common IGF1, IGFBP1 and IGFBP3 genetic variation with prospective IGF-I and IGFBP-3 blood levels and prostate cancer risk among Caucasians. Hum Mol Genet 2010;19:3089-3101.

-11 Costalonga EF, Antonini SR, Guerra-Junior G, Mendonca BB, Arnhold IJP, Jorge AAL: The -202 A allele of insulin-like growth factor binding protein-3 (IGFBP3) promoter polymorphism is associated with higher IGFBP-3 serum levels and better growth response to growth hormone treatment in patients with severe growth hormone deficiency. J Clin Endocrinol Metab 2009;94:588595.

12 van der Kaay DC, Hendriks AE, Ester WA, Leunissen RW, Willemsen RH, de Kort SW, Paquette JR, Hokken-Koelega AC, Deal CL: Genetic and epigenetic variability in the gene for IGFBP-3 (IGFBP3): correlation with serum IGFBP-3 levels and growth in short children born small for gestational age. Growth Horm IGF Res 2009;19:198-205.

13 Dunger OK, Huxtable SJ, Sherriff A, Woods KA, Ahmed ML, Golding J, Pembrey ME, Ring S, Bennett ST, Todd JA: Association of the INS VNTR with size at birth. Nat Genet 1998;19:98-100.

14 Vaessen N, Janssen JA, Heutink P, Hofman A, Lamberts SW, Oostra BA, Pols HA, van Duijn CM: Association between genetic variation in the gene for insulin-like growth factor-I and low birthweight. Lancet 2002; 359:1036-1037.

- 15 Frayling TM, Hattersley AT, McCarthy A, Holly J, Mitchell SM, Gloyn AL, Owen K, Davies D, Smith GD, Ben-Shlomo Y: A putative functional polymorphism in the IGF-I gene: association studies with type 2 diabetes, adult height, glucose tolerance, and fetal growth in UK populations. Diabetes 2002; 51:2313-2316.

16 Mitchell SM, Hattersley AT, Knight B, Turner T, Metcalf BS, Voss LD, Davies D, McCarthy A, Wilkin TJ, Smith GD, Ben-Shlomo Y, Frayling TM: Lack of support for a role of the insulin gene variable number of tandem repeats minisatellite (INS-VNTR) locus in fetal growth or type 2 diabetes-related intermediate traits in United Kingdom populations. J Clin Endocrinol Metab 2004;89: 310-317.

17 Mook-Kanamori DO, Miranda Geelhoed JJ, Steegers EA, Witteman JC, Hofman A, Moll HA, van Duijn CM, Hokken-Koelega AC, Jaddoe VW: Insulin gene variable number of tandem repeats is not associated with weight from fetal life until infancy: the Generation R Study. Eur J Endocrinol 2007;157:741-748.

- 18 Maas JA, Mook-Kanamori DO, Ay L, Steegers EA, van Duijn CM, Hofman A, Hokken-Koelega AC, Jaddoe VW: Insulin VNTR and IGF-1 promoter region polymorphisms are not associated with body composition in early childhood: the generation $\mathrm{R}$ study. Horm Res Paediatr 2010;73:120-127.

19 Vafiadis P, Bennett ST, Colle E, Grabs R, Goodyer CG, Polychronakos C: Imprinted and genotype-specific expression of genes at the IDDM2 locus in pancreas and leucocytes. J Autoimmun 1996;9:397-403.

20 Pugliese A, Zeller M, Fernandez A Jr, Zalcberg LJ, Bartlett RJ, Ricordi C, Pietropaolo M, Eisenbarth GS, Bennett ST, Patel DD: The insulin gene is transcribed in the human thymus and transcription levels correlated with allelic variation at the INS VNTR-IDDM2 susceptibility locus for type 1 diabetes. Nat Genet 1997;15:293-297.

21 Paquette J, Giannoukakis N, Polychronakos C, Vafiadis P, Deal C: The INS 5' variable number of tandem repeats is associated with IGF2 expression in humans. J Biol Chem 1998;273:14158-14164.

22 Gluckman PD, Hanson MA: Living with the past: evolution, development, and patterns of disease. Science 2004;305:1733-1736.

23 McMillen IC, Robinson JS: Developmental origins of the metabolic syndrome: prediction, plasticity, and programming. Physiol Rev 2005;85:571-633.

24 Harder T, Rodekamp E, Schellong K, Dudenhausen JW, Plagemann A: Birth weight and subsequent risk of type 2 diabetes: a metaanalysis. Am J Epidemiol 2007;165:849-857.

25 LeRoith D, Yakar S: Mechanisms of disease: metabolic effects of growth hormone and insulin-like growth factor 1. Nat Clin Pract Endocrinol Metab 2007;3:302-310.

26 Clemmons DR: Involvement of insulin-like growth factor-I in the control of glucose homeostasis. Curr Opin Pharmacol 2006;6: 620-625.

27 Hunt KJ, Lukanova A, Rinaldi S, Lundin E, Norat T, Palmqvist R, Stattin P, Riboli E, Hallmans G, Kaaks R: A potential inverse association between insulin-like growth factor
I and hypertension in a cross-sectional study. Ann Epidemiol 2006;16:563-571.

28 Ezzat VA, Duncan ER, Wheatcroft SB, Kearney MT: The role of IGF-I and its binding proteins in the development of type 2 diabetes and cardiovascular disease. Diabetes Obes Metab 2008;10:198-211.

29 Perticone F, Sciacqua A, Perticone M, Laino I, Miceli S, Care I, Galiano Leone G, Andreozzi F, Maio R, Sesti G: Low plasma insulin-like growth factor-1 levels are associated with impaired endothelium-dependent vasodilatation in a cohort of untreated hypertensive Caucasian subjects. J Clin Endocrinol Metab 2008;93:2806-2810.

30 Voigt M, Schneider KT, Jahrig K: Analysis of a 1992 birth sample in Germany. 1: New percentile values of the body weight of newborn infants (in German). Geburtshilfe Frauenheilkd 1996;56:550-558.

-31 Mook-Kanamori DO, Steegers EA, Uitterlinden AG, Moll HA, van Duijn CM, Hofman A, Jaddoe VW: Breast-feeding modifies the association of PPARgamma2 polymorphism Pro12Ala with growth in early life: the Generation R Study. Diabetes 2009;58:992-998.

32 Adkins RM, Fain JN, Krushkal J, Klauser CK, Magann EF, Morrison JC: Association between paternally inherited haplotypes upstream of the insulin gene and umbilical cord IGF-II levels. Pediatr Res 2007;62:451-455.

33 Bennett ST, Todd JA: Human type 1 diabetes and the insulin gene: principles of mapping polygenes. Annu Rev Genet 1996;30:343370.

34 Landmann E, Geller F, Schilling J, Rudloff S, Föller-Gaudier E, Gortner L: A polymorphism in the insulin-like growth factor I promoter gene but not in the insulin gene variable number of tandem repeat locus is associated with accelerated weight gain in infancy. Pediatrics 2006;118:2374-2379.

35 Blum WF, Ranke MB: Use of insulin-like growth factor-binding protein 3 for the evaluation of growth disorders. Horm Res 1990; 3:31-37.

36 Blum WF, Schweizer R: Insulin-like growth factors and their binding proteins; in Ranke MB (ed): Diagnostics of Endocrine Function in Children and Adolescents. Basel, Karger, 2003, pp 166-199.

-37 Baglietto L, English DR, Hopper JL, Morris HA, Tilley WD, Giles GG: Circulating insulin-like growth factor-I and binding protein-3 and the risk of breast cancer. Cancer Epidemiol Biomarkers Prev 2007;16:763768.

38 Severi G, Morris HA, MacInnis RJ, English DR, Tilley WD, Hopper JL, Boyle P, Giles GG: Circulating insulin-like growth factor-I and binding protein-3 and risk of prostate cancer. Cancer Epidemiol Biomarkers Prev 2006;15:1137-1141.

39 Chan SS, Twigg SM, Firth SM, Baxter RC: Insulin-like growth factor binding protein-3 leads to insulin resistance in adipocytes. J Clin Endocrinol Metab 2005;90:6588-6595. 
40 Kim HS, Ali O, Shim M, Lee KW, Vuguin P, Muzumdar R, Barzilai N, Cohen P: Insulinlike growth factor binding protein-3 induces insulin resistance in adipocytes in vitro and in rats in vivo. Pediatr Res 2007;61:159-164.

41 Ong KK, Petry CJ, Barratt BJ, Ring S, Cordell HJ, Wingate DL, Pembrey ME, Todd JA, Dunger DB: Maternal-fetal interactions and birth order influence insulin variable number of tandem repeats allele class associations with head size at birth and childhood weight gain. Diabetes 2004;53:1128-1133.

42 Bennett AJ, Sovio U, Ruokonen A, Martikainen H, Pouta A, Taponen S, Hartikainen AL, King VJ, Elliott P, Jarvelin MR, McCarthy MI: Variation at the insulin gene VNTR (variable number tandem repeat) polymorphism and early growth: studies in a large Finnish birth cohort. Diabetes 2004;53 2126-2131.
43 Levitt NS, Lambert EV, Woods D, Hales CN, Andrew R, Seckl JR: Impaired glucose tolerance and elevated blood pressure in low birth weight, nonobese, young South African adults: early programming of cortisol axis. J Clin Endocrinol Metab 2000;85:4611-4618.

44 Kingdom JC, McQueen J, Connell JM, Whittle MJ: Fetal angiotensin II levels and vascular (type I) angiotensin receptors in pregnancies complicated by intrauterine growth retardation. Br J Obstet Gynaecol 1993;100: 476-482.

45 Jaquet D, Deghmoun S, Chevenne D, Collin D, Czernichow P, Levy-Marchal C: Dynamic change in adiposity from fetal to postnatal life is involved in the metabolic syndrome associated with reduced fetal growth. Diabetologia 2005;48:849-855.

46 Fagerberg B, Bondjers L, Nilsson P: Low birth weight in combination with catch-up growth predicts the occurrence of the metabolic syndrome in men at late middle age: the Atherosclerosis and Insulin Resistance study. J Intern Med 2004;256:254-259.

47 Hemachandra AH, Howards PP, Furth SL, Klebanoff MA: Birth weight, postnatal growth, and risk for high blood pressure at 7 years of age: results from the Collaborative Perinatal Project. Pediatrics 2007;119:12641270
8 Rosen CJ, Kurland ES, Vereault D, Adler RA, Rackoff PJ, Craig WY, Witte S, Rogers J, Bilezikian JP: Association between serum insulin growth factor-I (IGF-I) and a simple sequence repeat in IGF-I gene: implications for genetic studies of bone mineral density. J Clin Endocrinol Metab 1998;83:2286-2290.

49 Vaessen N, Heutink P, Janssen JA, Witteman JC, Testers L, Hofman A, Lamberts SW, Oostra BA, Pols HA, van Duijn CM: A polymorphism in the gene for IGF-I: functional properties and risk for type 2 diabetes and myocardial infarction. Diabetes 2001;50: 637-642.

50 Kinoshita Y, Kizaki Z, Ishihara Y, Nakajima H, Adachi S, Kosaka K, Kinugasa A, Sugimoto T: The relationship in Japanese infants between a genetic polymorphism in the promoter region of the insulin-like growth factor I gene and the plasma level. Neonatology 2007;92:116-119. 